\title{
THE ASSOCIATION OF BRONCHIAL CARCINOID AND PLURIGLANDULAR ADENOMATOSIS
}

\author{
BY \\ E. D. WILliams* and L. R. CELESTIN \\ From the Departments of Pathology and Surgery, Postgraduate Medical School, Ducane Road, \\ London, W.12
}

(RECEIVED FOR PUBLICATION OCTOBER 31, 1961)

The syndrome of multiple endocrine adenomas in which pituitary, parathyroid, pancreatic islets, and adrenals may be involved has received much attention recently, mainly because of its intricate relationship to the Zollinger-Ellison syndrome, which associates non-beta pancreatic islet tumours with recurrent peptic ulceration. One of the interesting facets of pluriglandular adenomatosis is its association with other unusual tumours ; in the case reported here a bronchial carcinoid was present. It is also one more example of a patient in whom the diagnosis of Zollinger-Ellison syndrome was considered during life, and who at necropsy had multiple endocrine tumours.

\section{Case Report}

J.C., a native of British Guiana, died in the Hammersmith Hospital at the age of 35 years. His first recorded illness was at 21 when he complained of abdominal pain which troubled him for nearly all his remaining 14 years of life. He was seen and treated at many hospitals, both in British Guiana and in Britain, and his illness was punctuated by so many operations, including nephrolithotomy, that a diagram (Fig. 1) will convey the relevant facts more clearly than an involved account. No family history of any related illness was obtained, but only scanty details were available.

The necropsy on this well-proportioned, coloured male was started three hours after death. Externally, apart from the scars of numerous operations, there was nothing of note ; in particular there were no subcutaneous tumours, although a lipoma had at one time been removed from the shoulder region. There was no suggestion of acromegaly.

The immediate cause of death was a generalized peritonitis resulting from a broken-down suture line between the small gastric remnant and the jejunum.

\footnotetext{
* Present address : The Bernhard Baron Institute of Pathology, The London Hospital, E.1.
}

The most striking findings were in the endocrine glands. The pituitary (Fig. 2) weighed $750 \mathrm{mg}$. and contained three small adenomas, each composed mostly of chromophobe cells with a small proportion of basophils. The pars nervosa was large and contained many giant nuclei and one small focus of granular P.A.S.-positive cells, changes resembling those described by Luse and Kernohan (1955) as their second type of granular cell tumour. There was adenomatous hyperplasia of the parathyroids. The largest of the four was the oval red-brown left upper parathyroid, which measured $21 \times 10 \times 5 \mathrm{~mm}$. and weighed $720 \mathrm{mg}$. The right upper parathyroid was also enlarged $(8 \times 4 \times 2 \mathrm{~mm}$., $50 \mathrm{mg}$.). Both contained waterclear, chief, and oxyphil cells, with chief cells predominating (Fig. 3). The two lower parathyroids were slightly larger than normal; histologically the normal structure was replaced by a follicular and trabecular pattern with a mixed cytology, the majority of cells being of the chief type. A single figure of $6.2 \mathrm{mEq}$./1. for the serum calcium shortly before death, combined with the history of renal stones, suggests that hyperparathyroidism was present. External examination of the pancreas $(82$ g.) revealed one tumour, a nodule $1 \mathrm{~cm}$. in diameter, projecting from the posterior surface of the head. Nine further tumours were found on sectioning the pancreas, all about $1 \mathrm{~cm}$. or less in diameter, with a homogeneous grey cut surface. The majority showed the typical islet-cell tumour pattern (Fig. 4) with anastomosing strands of small cells separated by loose connective tissue or more dense fibrous tissue; all these pancreatic tumours were thought to be of islet-cell origin. A small submucosal nodule in the duodenum showed a similar histological appearance and was presumed to be an eleventh primary islet-cell tumour in ectopic pancreas. This duodenal tumour and one of the pancreatic tumours showed invasion of the surrounding tissue and were considered to be 


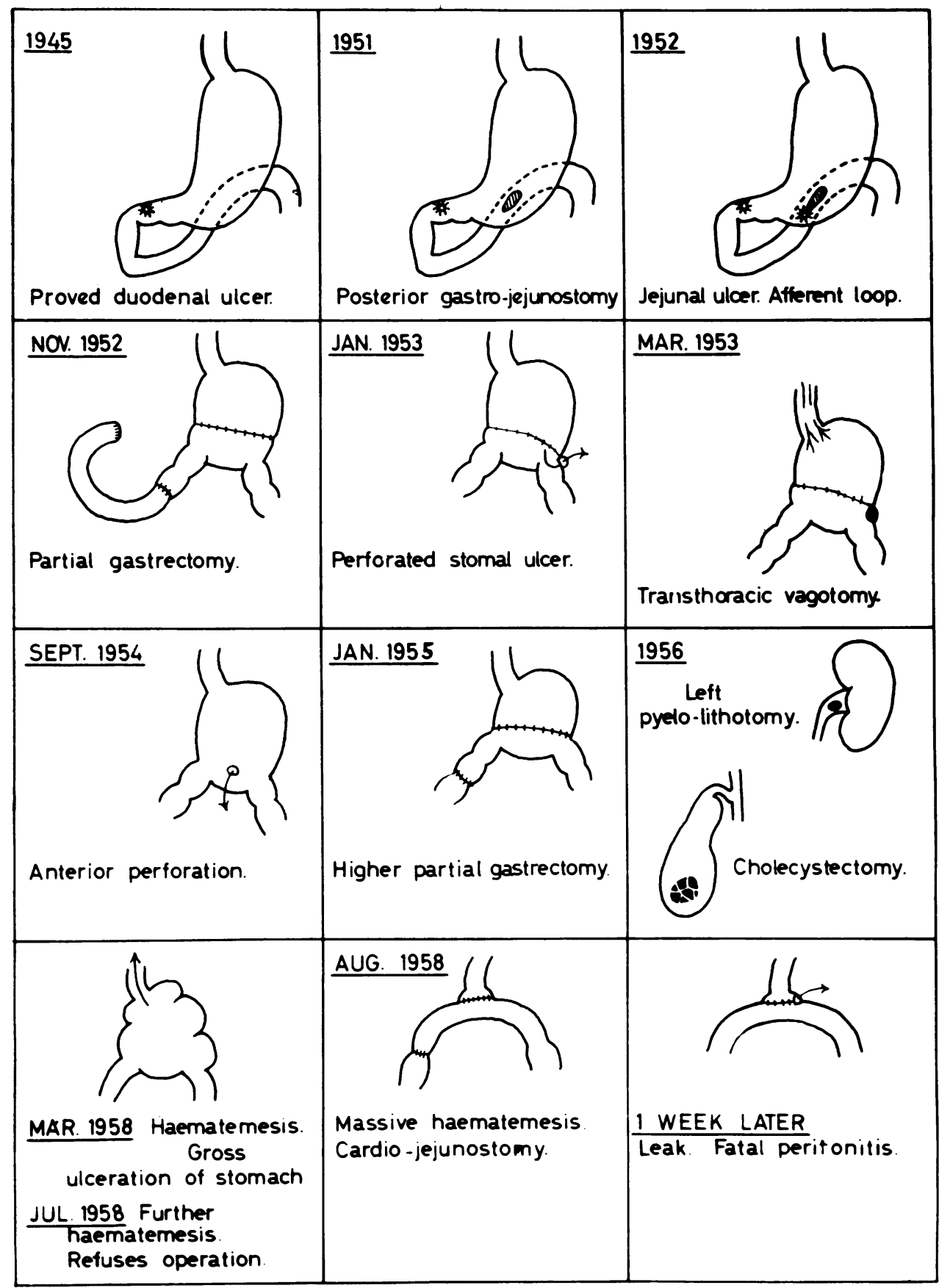

FIG. 1.-Diagrammatic representation of case nistory. 


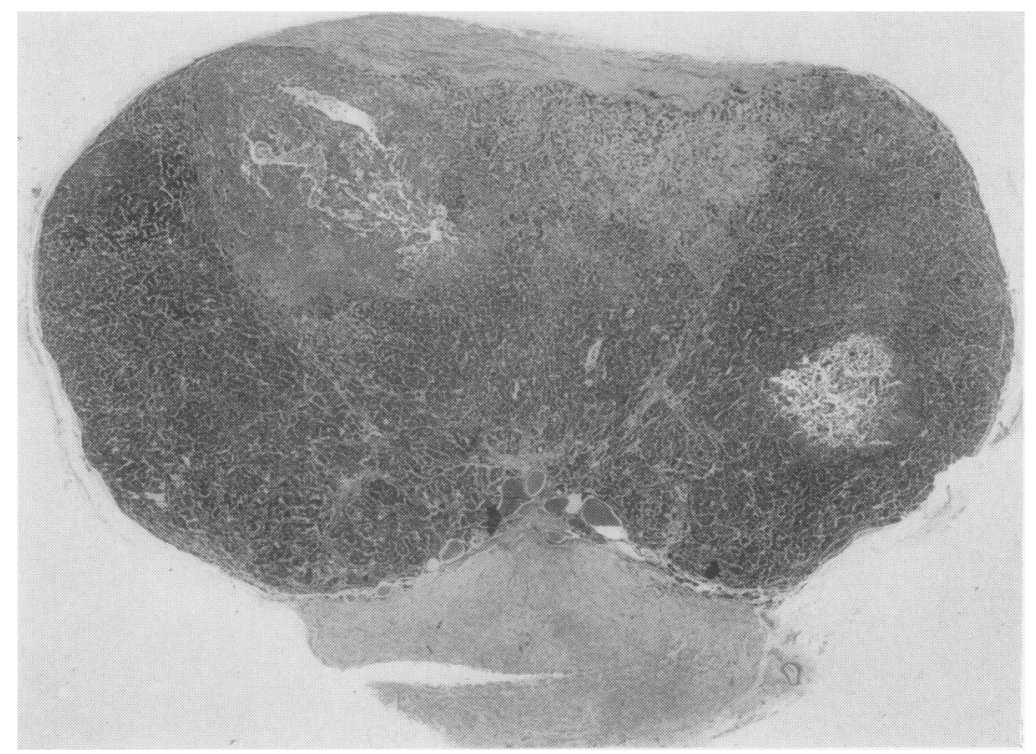

FIG. 2.-Multiple small pituitary adenomas. Haematoxylin and eosin, $\times 8$.

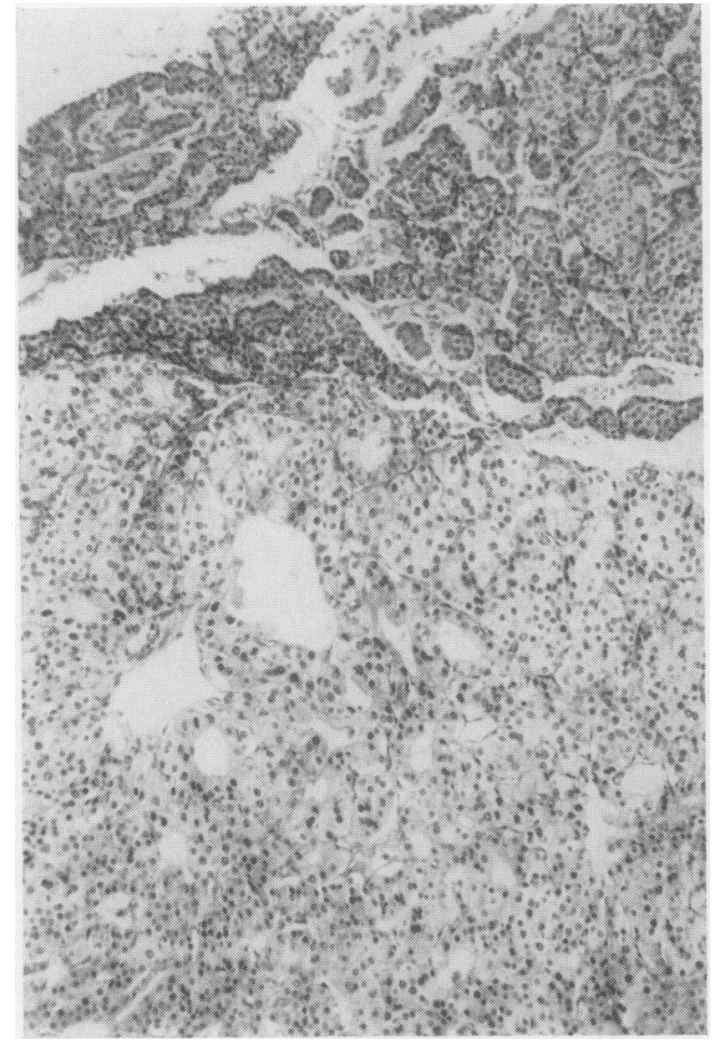

FIG. 3.-Mixed cytology and pattern in the leit upper parathyroid. Haematoxylin and eosin, $\times 100$. islet-cell carcinomas. Single small deposits of metastatic islet-cell carcinoma were found in one pancreatic-splenic lymph node and in the liver. Gomori's aldehyde-fuchsin technique did not demonstrate cytoplasmic granules in any of the tumours, and there is therefore no evidence of a beta-cell origin. With Masson's trichrome method, cells with fine red cytoplasmic granules were seen in varying numbers in six tumours; this suggests an origin from, or a differentiation towards, alpha cells. The islets of the nontumorous parts of the pancreas were hypertrophied and contained an increased number of alpha cells. Both suprarenals were greatly enlarged (Fig. 5), the right weighing $16 \mathrm{~g}$. and the left $22 \mathrm{~g}$. The cortex measured up to $0.7 \mathrm{~cm}$. in thickness, and there were all stages of gradation between nodular hyperplasia and discrete cortical adenomas. The largest adenoma was on the left side and measured $1.2 \mathrm{~cm}$. in diameter. Histologically most of the cells were of the lipoid-rich type. The testes weighed $60 \mathrm{~g}$. together and showed some reduction in spermatogenesis but no other abnormality. The thymus was replaced by fat. The pineal was normal.

In the respiratory system the main abnormality was in the lower lobe of the left lung. The posterior basal segmental bronchus was blocked by a soft grey-brown pedunculated tumour, macroscopically typical of bronchial adenoma. The stalk was continuous with an extrabronchial mass of tumour $1.8 \mathrm{~cm}$. in diameter. The bronchi 
FIG. 4.-Trabecular arrangement in an islet-cell tumour of the pancreas. Haematoxylin and eosin, $\times 40$.

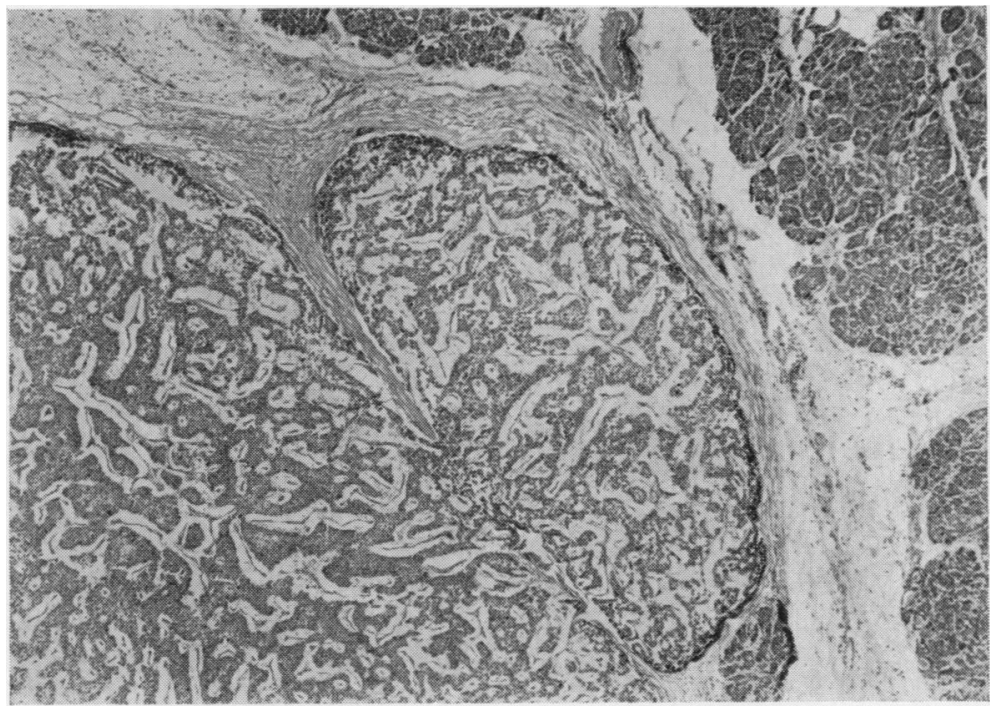

distal to the tumour were distended by mucus and contained a second smaller pedunculated tumour. A separate parenchymal nodule of firm white growth, $1 \mathrm{~cm}$. in diameter, was present immediately beneath the adjacent pleura. Sections of these tumours showed the characteristic carcinoid histological pattern (Fig. 6). From the macroscopic appearances it seems likely that there were at least two separate primary tumours. The hilar lymph nodes were free of growth. There was a single subpleural nodule of inactive caseous tuberculosis on the lateral aspect of the left upper

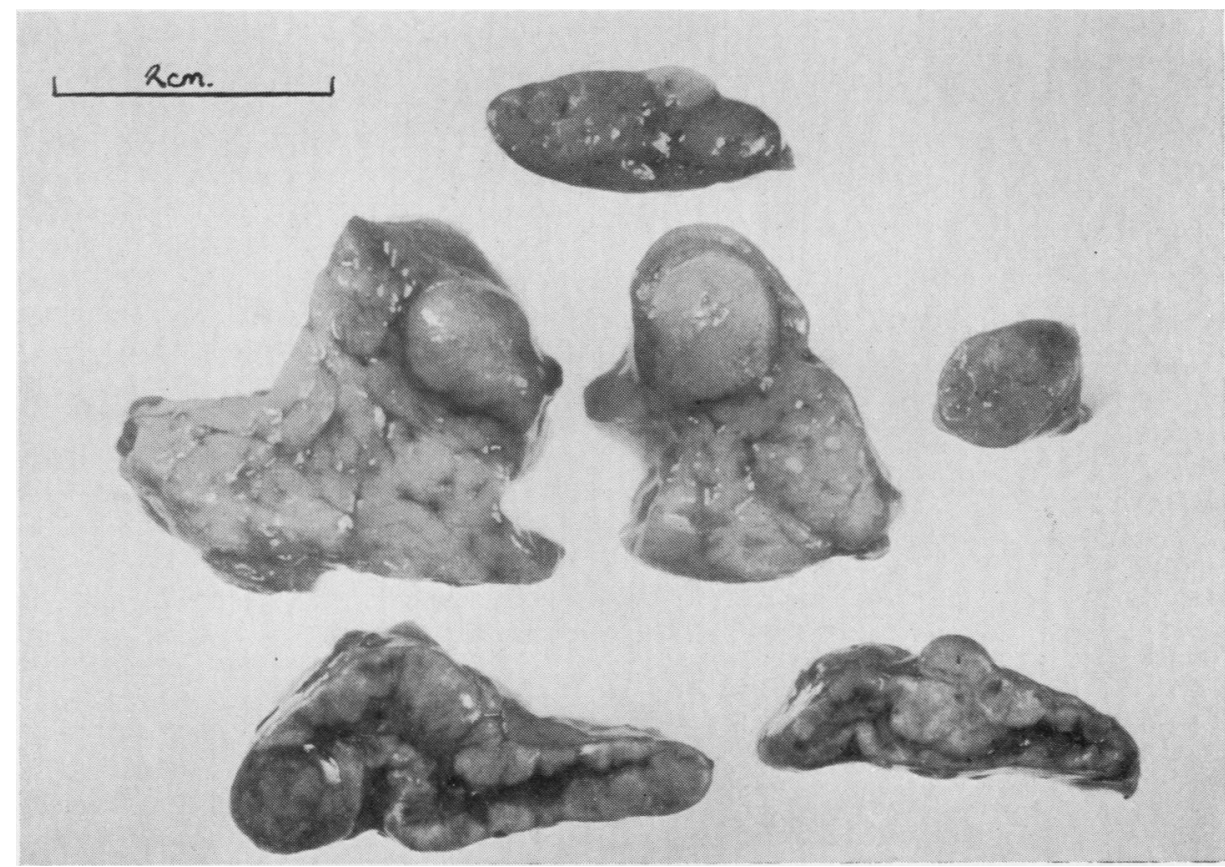

FIG. 5.-Top: Cut surface of largest parathyroid. Middle: Cross-section of head, body, and tail of pancreas to show the multiple islet-cell tumours. Bottom : Cross-section of left and right suprarenals. 


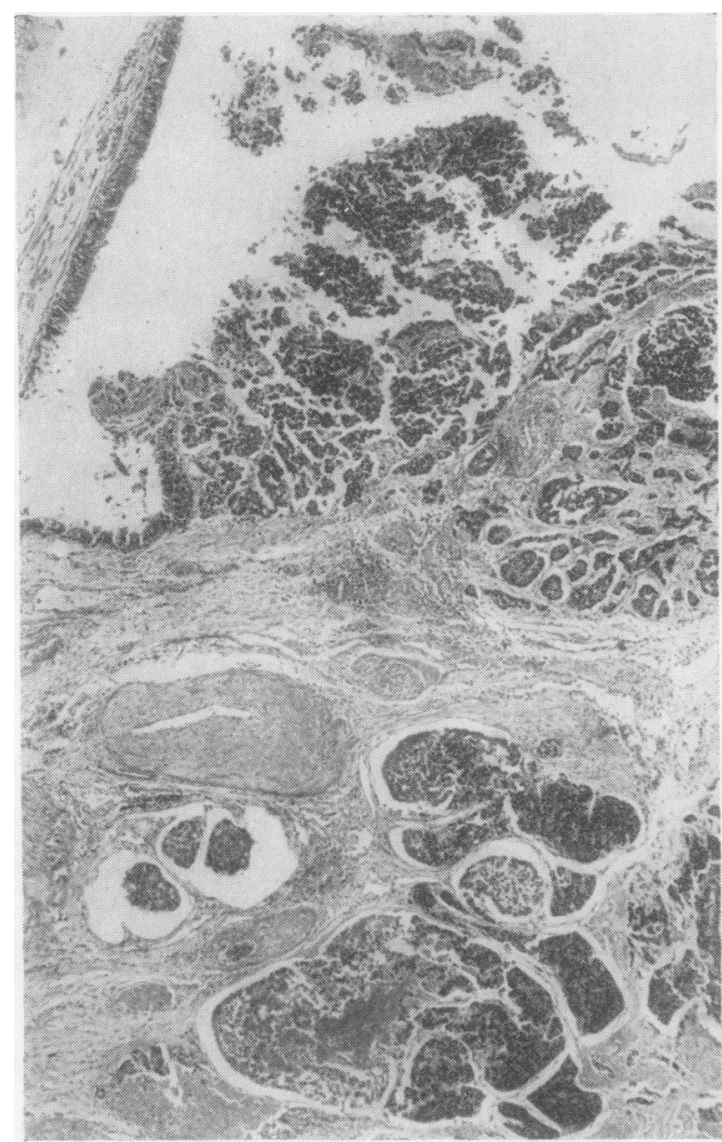

FIG. 6.-Intra- and extra-luminal bronchial carcinoid. Normal bronchial mucosa and cartilage at upper left. Haematoxylin and eosin, $\times 40$.

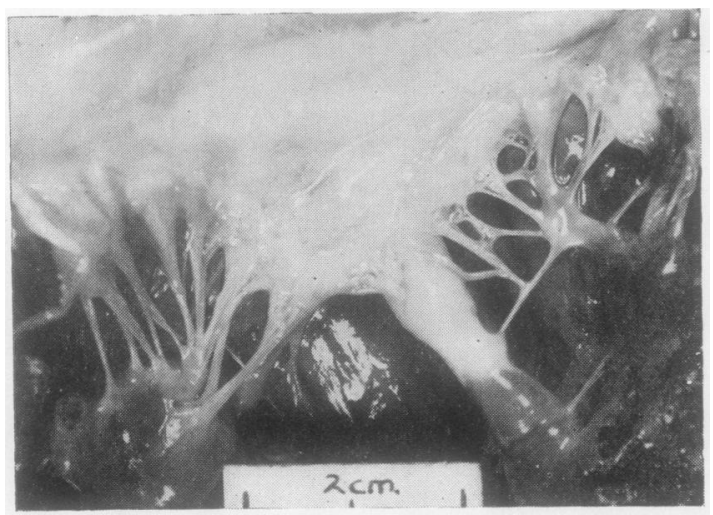

FIG. 7.-Diffuse fibrous thickening of the aortic cusp of the mitral valve with fusion of one group of chordae tendineae. lobe. The pleural cavity over the left lower lobe was obliterated by dense fibrous tissue.

The heart showed dilatation and hypertrophy of the left ventricle, which measured $2 \mathrm{~cm}$. in thickness. The foramen ovale was closed. The mitral valve (Fig. 7) showed a diffuse fibrous thickening. On section the normal elastic structure of the valve was undisturbed and no abnormal thick-walled vessels were seen. The fibrous tissue thickening was present on both sides of the valve leaflet and showed focal mucoid change and a small number of mast cells. The aortic cusp of the mitral valve was joined to one papillary muscle by a thick cylindrical band of glistening mature fibrous tissue replacing the chordae tendineae. The remaining chordae tendineae were only slightly thickened and the other valves showed no abnormality. There was nothing else of note in the cardiovascular system.

The mucosa of the very small gastric remnant showed an area of ulceration $2 \mathrm{~cm}$. in diameter encircling the cardia and was otherwise extremely rugose. Many oxyntic cells were present. The remains of the enormous ulcers seen at the final laparotomy were still present and eroded the liver, spleen, and left dome of the diaphragm. The duodenal stump was soundly closed. The isletcell carcinoma previously mentioned formed a nodule $1 \mathrm{~cm}$. in diameter in the second part of the duodenum. No other tumours were found in the small or large intestines.

The scar of the old nephrolithotomy was seen; histologically both kidneys showed many deposits of calcium in the collecting tubules and a diffuse fibrosis. In the skeletal system the bony trabeculae were delicate, but there was no osteitis fibrosa.

The other findings at the necropsy included one cavernous haemangioma, $1.3 \mathrm{~cm}$. in diameter, in the liver and a second, about $4 \mathrm{~cm}$. in diameter, in the spleen. There was a leiomyoma, $2.8 \times 1.5 \times 1.5 \mathrm{~cm}$. in the scrotum and a smaller one between the prostate and the left seminal vesicle.

\section{Discussion}

Our case obviously falls into the group which has been given the name "pluriglandular adenomatosis," individual cases of which have been known for many years, including one example in a dog (Perlman, 1944), but which was first adequately reviewed by Underdahl, Woolner, and Black (1953). Since that article several small series or single cases have been reported, as has a familial incidence (Wermer, 1954). The disease consists of adenomatous enlargement of various endocrine glands, the usual combination being pituitary, parathyroids, pancreatic islets, and 
adrenals. Tumours of mesodermal origin have occasionally been recorded, for instance a case reported by Marshall and Sloper (1954) with a giant lipoma. The extremely severe recurrent peptic ulceration present in this case has been shown by several other cases of pluriglandular adenomatosis. The association between intractable peptic ulceration and pancreatic non-betacell islet adenomas was described by Zollinger and Ellison (1955). A high incidence of peptic ulceration is known to occur in patients with hyperthyroidism and also with metastatic carcinoids (MacDonald, 1956). A surprisingly large number of patients with ulcerogenic tumour of the pancreas also show disease of other endocrines (one-quarter of a series of 72 quoted by Ellison in 1958 ; and others of this series may not have had other endocrine disease adequately excluded). Donaldson, von Eigen, and Dwight (1957), Frantz (1959), and Murphy, Goodsitt, Morales, and Bilton (1960) have been reluctant to accept the causal relationship between pancreatic islet tumours and peptic ulceration as adequately established; recent evidence on the presence of an ulcerogenic factor in extracts of these tumours is strongly suggestive if not quite conclusive. Our case is one more example of the association of severe peptic ulceration with multiple islet-cell tumours and adenomas of other endocrines.

One of the most interesting findings in the present case was a bronchial carcinoid. These tumours have long led to confusion because they have been called bronchial adenomas, despite their invasiveness and occasional metastases. Their histology, behaviour, and occasional ability to produce the carcinoid syndrome have recently been put forward as evidence in favour of their close relationship to intestinal carcinoids (Williams and Azzopardi, 1960). Since this review, several further cases of the carcinoid syndrome associated with a malignant bronchial carcinoid have been reported.

There were two points in the present case which suggested that the bronchial tumour might be secreting serotonin although the patient had not been noted to show any signs of the carcinoid syndrome in life. Over a litre of urine was present in the bladder at necropsy, and the 5-hydroxy-indole acetic acid (5-H.I.A.A.) content was $2.7 \mathrm{mg}$. $/ 100 \mathrm{ml}$. The upper limit of normal for 5 -H.I.A.A. secretion is $10 \mathrm{mg}$. $/ 24$ hours, and we would estimate the figure in this patient, who was adequately hydrated, as approximately 30 mg./24 hours. The fibrous thickening of the mitral valve did not show any evidence of rheumatic disease and the histological picture was compatible with carcinoid valvular disease. The fusion of chordae from one cusp to form a solid cord of dense fibrous tissue is often seen in this condition, and we interpret this as left-sided carcinoid valvular disease due to a functioning bronchial carcinoid. Bernheimer, Ehringer, Heistracher, Kraupp, Lachnit, Obiditsch-Mayer, and Wenzl (1960) have reported a case of bronchial carcinoid without metastases in which there was a diffuse but not very severe fibrosis of the endocardium and valves of the left side of the heart.

There have been several isolated case reports connecting bronchial carcinoid with other endocrine conditions (Table I). One patient with a raised 5-H.I.A.A. described by Southren (1960) showed acromegalic features and a large pituitary fossa, and Weiss and Ingram (1961), in a paper emphasizing the distinction between bronchial carcinoids and cylindromas, report one example (Case 9) of a bronchial carcinoid in a patient with acromegaly. Altmann and Schütz (1959) have also reported a case of acromegaly with a bronchial carcinoid. Bronchial carcinoids have been reported twice before in patients with undoubted pluriglandular adenomatosis; one of the cases reported by Underdahl et al. (1953) was said to have had a metastasizing bronchial adenoma; histologically, this was of the carcinoid type (Woolner, personal communication). One case reported by Goldman (1949) and by Goldman and

TABLE I

BRONCHIAL CARCINOIDS AND ENDOCRINE DISTURBANCES

\begin{tabular}{|c|c|c|c|c|c|}
\hline Author & $\begin{array}{l}\text { Age } \\
\text { (yr.) }\end{array}$ & Sex & $\begin{array}{c}\text { Associated } \\
\text { Endocrine } \\
\text { Disturbances }\end{array}$ & $\begin{array}{l}\text { Urine } \\
5- \\
\text { I.I.A.A } \\
\text { (mg.l } \\
24 \mathrm{hr} .)\end{array}$ & $\begin{array}{l}\text { Meta- } \\
\text { static } \\
\text { Car- } \\
\text { cinoid }\end{array}$ \\
\hline Goldman (1949) & 46 & $\mathbf{F}$ & $\begin{array}{l}\text { Multiple adenomas } \\
\text { of pituitary and } \\
\text { adrenals; large } \\
\text { pineal }\end{array}$ & $一$ & Yes \\
\hline $\begin{array}{l}\text { Underdahl et al. } \\
\text { (1953) }\end{array}$ & 36 & $\mathbf{M}$ & $\begin{array}{l}\text { Multiple parathyroid } \\
\text { adenomas; } \\
\text { hypoglycaemia }\end{array}$ & d - & , \\
\hline $\begin{array}{l}\text { Altmann and } \\
\text { Schütz (1959) }\end{array}$ & 47 & $\mathbf{F}$ & Acromegaly & - & No \\
\hline $\begin{array}{l}\text { Southren (1960) } \\
\text { Cohen et al. (1960) }\end{array}$ & $\begin{array}{r}22 \\
+33 \\
22\end{array}$ & $\mathbf{F}$ & Cushïing's syndrome & $21 \cdot 3$ & $\begin{array}{l}\text { Yes } \\
\text { No }\end{array}$ \\
\hline Greenbaum (1960) & $\begin{array}{r}23 \\
28\end{array}$ & $\stackrel{\mathbf{F}}{\mathbf{F}}$ & $\begin{array}{l}\text { Family history of } \\
\text { multiple para- } \\
\text { thyroid adenomas }\end{array}$ & - & Ÿes \\
\hline $\begin{array}{l}\text { Weiss and } \\
\text { Ingram (1961) }\end{array}$ & 45 & $\mathbf{M}$ & Acromegaly & - & , \\
\hline Christy (1961) & 57 & $\mathbf{F}$ & Cushing's syndrome & $\overline{7}$ & " \\
\hline $\begin{array}{l}\text { Escovitz and } \\
\text { Reingold (1961) }\end{array}$ & 39 & $\mathbf{M}$ & , & 27 & 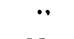 \\
\hline This paper & 35 & $\mathbf{M}$ & $\begin{array}{l}\text { Multiple adenomas } \\
\text { of pituitary, } \\
\text { parathyroids, } \\
\text { adrenals, and } \\
\text { pancreatic islets }\end{array}$ & c. 30 & No \\
\hline
\end{tabular}


Conner (1950) had a 20-year history of a bronchial lesion and at necropsy was found to have adenomas of the pituitary and both adrenals, an enlarged pineal, and a malignant carcinoid type of bronchial adenoma. Greenbaum (1960) has recently reported a family which shows various features of pluriglandular adenomatosis; one member had had a bronchial carcinoid with lymph node metastases removed. Both her father and sister have had hyperparathyroidism with multiple parathyroid adenomas, and her aunt has had renal calculi and secondary amenorrhoea. Both sister and aunt have an enlarged pituitary fossa. Cushing's syndrome is also recorded in association with bronchial carcinoids. Escovitz and Reingold (1961) have reported one case of Cushing's syndrome with both bronchial and intestinal carcinoids, and Christy (1961) recorded a malignant carcinoid tumour, with a primary probably in the lung, in a case of Cushing's syndrome. The two cases described by Cohen, Toll, and Castleman (1960) as Cushing's syndrome associated with peripheral bronchial adenomas obviously belong to this group.

Carcinoid tumours of the intestines are only very rarely associated with endocrine disturbances other than the carcinoid syndromes. One case of a carcinoid tumour of the duodenum associated with the pluriglandular syndrome has been reported by Fisher and Hicks (1960) and another by Gerber and Shields (1960). A rectal carcinoid in an acromegalic patient has been recorded by Buse, Buse, and Roberts (1961). It is interesting that malignant carcinoid tumours arising from the lower ileum, the commonest site of origin, do not seem to show this association.

The association between bronchial carcinoids and other endocrine tumours is obviously more than a casual one, but while its documentation is straightforward its explanation is elusive. The nature and function of the cell giving rise to the bronchial carcinoid are not at present known, but analogy with the intestinal carcinoids suggests that it is an endocrine cell. The presence of bronchial carcinoids as part of pluriglandular adenomatosis correlates well with this concept of an endocrine tumour and suggests that the cell of origin responds to the same unknown stimulus as the other endocrine cells. The association with acromegaly or Cushing's syndrome may represent one facet of this relationship, but it is worth noting that the other lung tumours which have been associated with Cushing's syndrome are oat-cell carcinomas. Two cases of oat-cell carcinoma with the carcinoid syndrome have been reported (Harrison, Montgomery, Robertson, Ramsey, and Welbourn, 1957 ; Williams and Azzopardi, 1960), and it may be that the bronchial carcinoid-Cushing's syndrome relationship has more in common with those cases of oat-cell carcinoma with Cushing's syndrome than with pluriglandular adenomatosis.

Whatever intricate endocrine relationships underlie these fascinating cases, the association between bronchial carcinoids and other endocrine conditions is a real though uncommon one. Our evidence suggests that, while the possibility of acromegaly, Cushing's syndrome, or pluriglandular adenomatosis should be considered in all patients with bronchial carcinoid, it is particularly important if there is evidence of metastasis or function of the carcinoid.

\section{SUMMARY}

The necropsy findings in a case of pluriglandular adenomatosis with recurrent peptic ulceration and a bronchial carcinoid are described.

The association of bronchial carcinoid with other endocrine tumours is reviewed. Among such cases the frequency of metastasis and secretion of serotonin by the bronchial carcinoid appears high. Evidence for the secretion of serotonin by the bronchial carcinoid in this case is presented.

The relationship between intractable ulceration, pancreatic islet-cell tumours, and other endocrine adenomas is briefly discussed.

We are grateful to Professors I. Doniach and C. V. Harrison for help and encouragement, and to $\mathrm{Mr}$. R. H. Franklin for permission to publish the clinical details. We would like to thank Mr. W. Brackenbury for the photographs.

\section{REFERENCES}

Altmann, H. W., and Schütz, W. (1959). Beitr. path. Anat., 120, 455. Bernheimer, H., Ehringer, H., Heistracher, P., Kraupp, O.. Lachnit, V., Obiditsch-Mayer, I., and Wenzl, M. (1960). Wien klin. Wschr., 72, 867.

Buse, J., Buse, M. G., and Roberts, W. J. (1961). J. clin. Endocr., 21, 735 .

Christy, N. P. (1961). Lancet, 1, 85.

Cohen, R. B., Toll, G. D., and Castleman, B. (1960). Cancer (Philad.), 13, 812 .

Donaldson, R. M., vom Eigen, P. R., and Dwight, R. W. (1957). New Engl. J. Med., 257, 965.

Ellison, E. H.. in discussion of paper by Oberhelman, H. A., Nelsen, T. S., and Dragstedt, L. R. (1958). A.M.A. Arch. Surg., 77, 414. Escovitz, W. E., and Reingold, I. M. (1961). Ann. intern. Med., 54, 1248.

Fisher, E. R., and Hicks, J. (1960). Gastroenterology, 38, 458.

Frantz, Virginia K. (1959). Atlas of Tumor Pathology. Sect. VII. Fasc. 27 and 28: Tumors of the Pancreas. Armed Forces Institute of Pathology, Washington, D.C. 
Gerber. B. C., and Shields, T. W. (1960). Arch. Surg. (Chicago), 81, 379.

Goldman, A. (1949). J. thorac. Surg., 18, 137.

- and Conner, C. L. (1950). Dis. Chest, 17, 644.

Greenbaum, D. (1960). Proc. roy. Soc. Med., 53, 903.

Harrison, M. T., Montgomery, D. A. D., Robertson, J. H., Ramsey, A. S., and Welbourn, R. B. (1957). Lancet, 1, 23.

Luse, Sarah A., and Kernohan, J. W. (1955). Cancer (Philad.), 8, 616.

MacDonald, R. A. (1956). Amer. J. Med., 21, 867.

Marshall, A. H. E., and Sloper, J. C. (1954). J. Path. Bact.,68, 225.
Murphy, R. T., Goodsitt. E., Morales. H., and Bilton, J. L. (1960). Amer. J. Surg., 100, 764

Perlman, R. M. (1944). Arch. Path. (Chicago), 38, 20.

Southren, A. L. (1960). J. clin. Endocr., 20, 298.

Underdahl, L. O.. Woolner, L. B., and Black, B. M. (1953). Ibid., 13,20 .

Weiss, L., and Ingram, Margaret (1961). Cancer (Philad.), 14, 161. Wermer, P. (1954). Amer. J. Med., 16, 363.

Williams, E. D., and Azzopardi, J. G. (1960). Thorax, 15, 30.

Zollinger, R. M., and Ellison, E. H. (1955). Ann. Surg., 142, 709. 